\title{
ПУБЛІЦИСТИКА ЮРІЯ ШЕВЕЛЬОВА В ГАЗЕТІ «СВОБОДА» (США)
}

\author{
Андрій Яценко \\ Львівський національний університет імені Івана Франка, \\ вул. Генерала Чупринки, 49, 79044, Львів, Україна, \\ e-mail: andrij-jacenko@i.ua \\ https://orcid.org/0000-0002-7137-8305
}

У запропонованій статті виокремлено головні ідейно-концептуальні засади політематичної публіцистики відомого мовознавця Юрія Шевельова на шпальтах «Свободи». Проаналізовано мовознавчий, подорожній, культурологічний та прогностичний аспекти виступів Юрія Шереха в найдавнішій україномовній американській газеті.

Ключові слова: Юрій Шевельов, газета «Свобода», публіцистика, мовознавчий аспект, подорожній аспект, прогностичний аспект, культура, національна ідея.

Публіцистика Юрія Шевельова на шпальтах україномовної американської газети «Свобода» - політематична і тривала у часі. Адже охоплює період з 1947 р. по 1993 р. багатогранність їі випливає із низки порушених проблем у задекларованому виданні. 3-поміж них варто виокремити виступи на мовознавчу, культурологічну тематику, а також звернути увагу на шерег подорожніх нарисів, так званих тревелогів. Відразу наголосімо, що, незважаючи на таку багатогранність, провідною ідеєю залишається ідея національна. Вона чітко випливає не лише 3 досліджень мовних, а й 3 культурологічних і з так званих харківських подорожніх нотаток.

Актуальність статті випливає з важливої проекції розуміння національних проблем (мовних, культурних, ментальних) у публіцистиці Ю. Шевельова на сучасність.

Новизна проблеми полягає в тому, що в статті вперше комплексно досліджено публіцистику Ю. Шевельова в американській газеті «Свобода» та виокремлено їі ідейно-концептуальні засади.

Огляд літератури. 3-поміж дослідників мовного компонента публіцистичної та наукової спадщини Юрія Шевельова варто виокремити Р. Зорівчак, В. Німчука, I. Дзюбу, Л. Масенко, М. Мозера, О. Микитюк, Л. Довбню та інших. Проте недослідженим залишається творчий доробок Юрія Шереха на шпальтах американської «Свободи». Певні аспекти його подорожньої публіцистики проаналізував І. Михайлин у контексті історичного та культурного розвитку Харкова [1].

Мета дослідження полягає у визначенні основних ідей, проблематики, концептуальних засад публіцистики Юрія Шевельова в американській газеті «Свобода», у виокремленні їі тематично-змістових моделей.

(C) Яценко А., 2019 
Мета статті передбачає розв'язання таких завдань:

- дослідити ідейно-концептуальні засади публіцистики Ю. Шевельова;

- систематизувати публіцистику Ю. Шевельова за різнотематичними її аспектами.

Мовознавчий аспект у публіцистиці Юрія Шевельова. Його основою стала аналітична стаття у газеті «Свобода» «Принципи і етапи большевицької політики щодо слов'янських мов у СРСР (крім російської)», яку оприлюднено в шести числах за 1947 р. Ця публікація була визначальною, на думку редакційного колективу американського щоденника, адже її передруковано також у радянський період, а саме: у 1982 р. [2: 3] і в 1983 р. [3: 3-4].

У зазначеному матеріалі відомий мовознавець чітко і послідовно вперше окреслює головних п’ять періодів розвитку української мови в більшовицькій епосі. Загалом у публікації зроблено акцент не тільки на українській, а й на білоруській мові. Ю. Шевельов зазначав, що політика щодо цих двох слов’янських мов «пройшла однакові етапи з тією різницею, що національна свідомість на Україні була вища» [4: 3], тому й сама Україна становила для більшовицько-окупантської влади більшу цінність.

Отож, мовознавець докладно характеризує особливості українізації у кожен період 3 негативним чи доволі сприятливим ставленням до неї тогочасної влади.

Перший період (до кіния 1919 р.) Ю. Шевельов окреслює як «безумовне ігнорування, заперечення й відкидання української мови» [4: 3], яке підкріплене словами Голови Ради Народних Комісарів Х. Раковського про те, що «декретування української мови як державної є реакційна, нікому не потрібна справа» [4: 3].

Другий період (1920-1923 рр.) мовознавець окреслює як етап сприяння розвитку української мови на законодавчому рівні, але за умов ігнорування і негативного ставлення до носіїв мови, так зване, за словами В. Винниченка, якого цитує Юрій Шерех, «підозріле відношення взагалі до всього українського...» [4: 3]. Це час боротьби двох сил, одна з яких була по-справжньому націлена на активацію процесів українізації, а інша, навпаки, компрометувала все, що 3 цим національним перетворенням пов'язане. Яскравим прикладом підтримки і розвитку усього українського стала, на думку Ю. Шевельова, діяльність двох мовознавчих шкіл, представниками яких були $Є$. Тимченко, О. Курило, О. Синявський. Обидві школи демонстрували цілісне бачення розвитку національних ідей. Проте вони залишалися ворожими для більшовицької влади, яка вела постійну боротьбу проти всього, націленого на активізацію нагальних для українського суспільства процесів українізації.

Третій період (1923-1929 рр.) - це своєрідне сприяння розвиткові самобутньої української мови. Адже саме в цей час активізується надважлива робота над повним академічним Словником української мови на чолі з академіком А. Кримським. Це особливий час введення в дію проукраїнського «Харківського правопису» («скрипниківки»), про який, до речі, Юрій Шерех неодноразово добре відгукувався на шпальтах «Свободи».

Четвертий період (1930-1938 рр.) відомий мовознавець, публіцист окреслює розгромом української культури, витісненням української мови з більшовицького порядку денного. Це час тотального наступу на все українське з боку тогочасного партійного керівництва. Ю. Шевельов для прикладу такої цілеспрямованої політики наводить статтю партійного діяча А. Хвилі «Викорінити, знищити націоналістичне 
коріння на мовному фронті». В окреслений період прихована русифікація полягала в повній заміні типових українських граматичних і синтаксичних конструкцій на російські. За таким принципом побудовано словникові статті «Російсько-українського словника» Інституту мовознавства (редактори: Н. Каганович і С. Василевський), який академік А. Кримський назвав російсько-російським словником [5: 3].

П’ятий період (1939-1941 рр.) - це час напруженої міжнародної ситуації напередодні Другої світової війни, що змусив тогочасну верхівку «перейти до деякого загравання з українцями» [6: 3]. Ю. Шевельов згадує виступи Ю. Яновського в «Літературній газеті» про збереження автентичності української мови. Пропагують активно наукові проблеми розвитку мови під керівництвом Л. Булаховського.

Загалом Ю. Шевельов підсумовує те, що насправді у жодному періоді навіть позитивні події, що нібито передували українізації, на жаль, не призупиняли цілеспрямованих процесів тотальної русифікації, які й ніколи не закінчувалися в радянську епоху і які продовжувалися лігвоцидами, етноцидами і геноцидами.

Подорожній аспект у публіцистиці Юрія Шевельова. Ще один блок статей Юрія Шевельова у газеті «Свобода» можна означити, як подорожні нариси, адже це нотатки $з$ подорожей до його «міста дитинства» - Харкова. Упродовж чотирьох років (з 1990 по 1994) мовознавець писав про враження від колишньої столиці України крізь призму бінарних дихотомій «свій-чужий», намагаючись правильно розставити акценти, показати історичну тяглість «українськості» Харкова, щоб врешті переконати не лише українців в діаспорі, а й автохтонних мешканців, у гіперважливій ролі колишньої столиці як «північно-східного аванпосту України». Відомий історик української журналістики Ігор Михайлин вважав, що це був дещо романтизований Харків: «П’ятий Харків - це мрія Ю. Шевельова. Це Харків, у якому реалізовано ідеал незалежної України» [1]. Хоча сенс, який вкладав Ю. Шевельов у поняття «п'ятий Харків», абсолютно дисонує 3 його першими враженнями від Харкова початку 90-х pp., бо, здається, що це місто, яке загубилося у часопростровових координатах минулого й майбутнього, а його амбівалентне теперішнє не може стати точкою відліку чогось нового. Свої «чотири Харкови» мовознавець акцентував ще у статті «Четвертий Харків», яку написав як післямову до книги Леоніда Лимана «Повість про Харків» у 1948 році. Отже, «Перший Харків» - це Харків слобід, хуторів, ремісників, це хліборобська ідилія в степах Слобожанщини, це ще Харків Григорія Сковороди, але вже й Харків російських чиновників. Минає півстоліття і місто абсолютно зросійщується. «Харків стає воротами Донбасу. Ворота отвором розчинені на північ. Покоління українських просвітян - у відступі і в обороні перед насуванням чужої сили. Харків для них ворог», - характеризує Ю. Шевельов «другий Харків» як символ наступу Москви на Україну [7]. Українська національна революціє приносить з собою «третій Харків»: «Харків Хвильового і ВАПЛІТЕ, Курбасового «Березоля», виставок АРМУ в залях колишнього манастиря, непримиренно-палких диспутів у Будинку літератури ім. Блакитного на Каплунівській, курсів сходознавства, українського студентства, українського походженням, душею, програмою і прагненням, поволі українізованих заводів і установ, неповторний, невідтворний, сповнений життя... Третій Харків, Харків нашої молодої молоді». Раптово постає «четвертий Харків»- це вирок всьому українському, це стан сірої провінційності, який триває в часі майже півстоліття.

Юрій Шевельов впізнає цю сірість і одноманітність під час перших відвідин Харкова у 1990 році. Він сам собі ставить риторичні запитання, чи місто має 
«українське серце», чи воно не застиглий взірець радянської епохи, а здатне до змін, до власної духовної еволюції. Центральною подією першого подорожнього нарису «Харків: подорожні враження і заклик» стали не університетські зустрічі відомого мовознавця, навіть не відвідини редакції якісного та проукраїнського видання «Прапор», а знайомство $з$ пересічним водієм таксі, який намагався розмовляти українською мовою та зробив щирий подарунок «американському професорові». Цей вчинок вразив Юрія Шевельова, бо яскраво заманіфестував той український кордоцентризм, який завжди був демаркаційною лінією між ментальностями східних слов'ян. Цей своєрідний інсайт став поштовхом до його подальших відвідин Харкова, до нових подорожніх нарисів, які з'являлися на шпальтах «Свободи», до історичних екскурсів, які робив Ю. Шевельов для українців-емігрантів, до постання того нового феномену Харкова, який може бути у двох наративах, східному та західному, але вже знаходиться в точці неповернення щодо радянського дискурсу. Він зрозумів, що зараз на порядку денному для Харкова стоїть питання творення національної ідентичності. «Місто затемненого обличчя, але потужної динаміки, і всім корінням і зв'язками в степу. Українському степу», - наголошував Ю. Шевельов на етнічній ідентичності харків'ян, яка має стати підгрунтям для творення національного самоусвідомлення [8: 2]. Оскільки основні риси національної ідентичності (за Ентоні Смітом) - це «історична територія або рідний край; спільні міфи та історична пам'ять; спільна масова, громадська культура; єдині юридичні права та обов'язки для усіх членів; спільна економіка з можливістю пересуватися у межах національної території», то публіцист акцентує саме на перших трьох. Він робить вдалий екскурс в історію Харкова, щоб показати, що категорія «рідного краю» $є$ у світогляді мешканців Харківщини, бо історично склалося так, що Дике Поле освоювали українські селяни, проте адміністративна верхівка була російська, з'їжджалося російське купецтво, а індустріалізація Східної України сприяла загрозі повної русифікації. «Глибинно, в коренях, у припливі свіжих сил з села Харків лишався українським, на поверхню пнялися поруч українських пагонів російські», - пише Ю. Шевельов [9: 2]. Отже, дуже важливими для творення національної ідентичності залишаються спільна історична пам'ять та культура, еволюцію яких можуть підтримати українці з діаспори. Харківські враження Ю. Шевельов вирішив надрукувати саме у «Свободі», бо газета якраз була символом закумульованої української ідентичності, адже виходила на американському континенті вже майже сто років, гуртувала навколо себе все діаспорне українство, генерувала нові форми взаємодії між колишніми земляками (Американська Руська Народна Рада, Український Конгресовий Комітет Америки, Український Народний Союз). Публікація Ю. Шевельова у «Свободі», як свідчить Ігор Михайлин, мала неабиякий резонанс, адже в газеті «Українські вісті», яка виходила тоді також у США, мовознавець опублікував невелику замітку «Від слів до діла: Харків хоче і може мати допомогу», у якій написав, що відгукнулося багато людей з Канади, США, Австралії, які зголосилися допомогти українському Харкову [1]. Це також мотивувало Ю. Шевельова разом з ініціативною групою «Друзі Харкова», до якої входили Оксана Соловей, Мар'ян Коць, Євген Федоренко, створити культурний фонд допомоги. У грудні 1992 року на шпальтах «Свободи» з'являється невеликий звіт, у якому опубліковано списки жертводавців та суму допомоги, яка надходила як від різних організацій та братств, так і від українців емігрантів. Значні пожертви на національну справу надіслала від українська громада з Лондона [10: 3]. 
Яиенко А.

У цьому ж числі з'являються знову подорожні нотатки Юрія Шевельова з чергових відвідин Харкова. Оптимістичний тон заголовка «Добрі новини з Харкова» інтонував всю публікацію, у якій публіцист акцентував на вагомому поступі у всіх царинах культурного життя Харкова. Особливий наголос він робив на тих суспільних трансформаціях, які маніфестували творення нової національної ідентичності у харків'ян. Відкриття пам'ятника Г. Сковороді, як проекція творення власного національного міфу, власного смислового поля, де присутні національний герой-інтелектуал, колективна пам’ять, неперервність національної екзистенції (Ю. Шевельов згадує про «Перший Харків» як місто, де вчить «української мудрости Грицько Сковорода»). Отже, пам'ятник Г. Сковороді не випадковий, це усвідомлене уособлення легітимності існування саме украӥнського Харкова.

Яскраві враження у Ю. Шевельова і від відвідин Івано-Богословської церкви та зустрічі з місцевим парохом: «Центр української автокефалії - Івано-Богословська церква, чию фотографію «Свобода» дала десь рік тому. Був я й там, був присутній на Богослужбі, говорив з привітним священиком о. Віктором Миринчаком. I ця церква стояла руїною, і цю церкву відродили священики і вірні, і ця перегороджена посередині - одна половина діє, друга закрита від людських очей, бо напівзруйнована, як і баня над нею. Церква не має опалення, вона на краю міста, i туди нелегко діставатися старим і немічним. Але надолужується це ентузіязмом і людяністю духівництва й парафіян» [11: 3]. Відновлення церкви - це не лише реконструкція історичної пам'яті, а й формування спільної духовної культури. Цією метою позначена й діяльність щойно заснованого товариства «Просвіта», новоствореної загальноуніверситетської кафедри української мови, історії, етнографії, культури, літератури, літературного музею та відновленого історично-філологічного товариства.

Акцентував Ю. Шевельов і на тих культурних нішах, які харків'яни мали б заповнити. Це підтримка українських видавництв та спорудження «пантеонів» пам'яті борцям за волю України, що вже давно зробили у Харкові поляки для своїх полеглих. «Вшанування вимагають і місця, де звалено тисячі і тисячі українських трупів. Злочин волає до неба. Не треба коментарів, але треба відзначити мовчазними каменями пам'ять загиблих, сьогодні для нас безіменних» [11: 4], - наголошує публіцист.

Аналіз третього подорожнього нарису Юрія Шевельова дозволяє зробити висновки, що для мовознавця національна культура - це іманентна умова існування нації. Публікація «Харків фестивальний та Харків на щодень» [12][13][14] - це враження від його чергових відвідин Харкова та Першого міжнародного фестивалю, який там проходив. Ю. Шерех констатує, що проведення цього фестивалю - ще один крок Харкова до утвердження власної українськості та демонстрація відкритості до культурного діалогу з культурним світом Європи та Росії. «Все це зібрано на тій землі, яка не має культурної професійної безперервности, якої ще три роки тому не було на культурній мапі Европи, - трудно утриматися від того, щоб не назвати цього чудом» [13: 2], - констатує він. Цей блок подорожніх нарисів пронизаний відчуттям моральної сатисфакції і гордості за місто свого дитинства, бо саме Ю. Шевельов був ініціатором групи «Друзі Харкова». «Український культурний Харків росте, росте бурхливо, задихаючися часом у своїх трудних і на перший погляд нерозв’язних проблемах, шукаючи зайвої копійки, хапаючися за соломинки, часом виринаючи, часом потопаючи... Він болюче потребує допомоги - і моральної і матеріяльної - грошима, комп’ютерами, буквально всім. Намагаються подавати її Друзі Харкова в Америці, 
не вимагаючи ніяких ідеологічннх пристосувань і партійних присяг» [14: 2], - наголошує мовознавець і закликає до залучення нових жертводавців.

Остання публікація з низки «харківських вражень» - «Добрі і не такі вже добрі новини з Харкова», у якій Ю. Шевельов з прикрістю констатує поразку демократичних сил у виборчій кампанії, але водночас робить зріз того культурного поступу Харкова, який йому вдалося зробити фактично за три роки: реставрація церков, розвиток українських театрів та музеїв, розвиток українського книговидавництва... Все це, звісно, з допомогою «Друзів Харкова», про діяльність яких мовознавець звітує у цьому нарисі та ставить перед собою та своїми соратниками нові завдання, бо «війна за Харків і в політиці і в культурі, мирна, але вперта, триває» [15: 2].

Культорологічний аспект у публіцистиці Юрія Шевельова. Культурологічна проблематика публіцистики Ю. Шевельова також багатогранна: від становлення Української вільної академії наук у США до розвитку книговидання на еміграції та новітніх постановок молодого українського театру. Лейтмотивом його статей, які з'явилися з 1954 по 1988 роки, було збереження української історичної пам'яті і водночас розвиток української науки та культури у світовому контексті, а не в історично застиглих традиціях. Варто наголосити, що важливу роль у творенні українського культурного «ренесансу» на еміграції відводив як старшому поколінню, батьківщиною якого була українська земля, так і молоді, яка вже народилася у США, але ментально мала б залишитися українською. Ю. Шевельов відчував екзестинційний страх неготовності старшого покоління еміграції перейти від етнічного культурного ядра до національного, а молодше покоління, на жаль, не завжди хотіло звернутися до свого етнічного менталітету, бо занадто магнетичними були впливи периферійних елементів інших культур. Саме тому, на нашу думку, кожну культурну подію Ю. Шевельов розглядав крізь призму формування української національної ідентичності. Наприклад, видання «Історії України-Руси» М. Грушевського він назвав «культурною подією» для всієї української діаспори. Адже з одного боку Грушевський-історик - це взірець для науковців Східної Європи (парадокс, але навіть історики СРСР звертаються до його багатого фактологічного матеріалу), тобто його наукові здобутки належать іманентно до європейської культури, бо «... жадна поважна історія Сходу Европи не можлива без цієї його праці» [16: 3]. Водночас праці М. Грушевського - це підвалини розвитку української національної ідеології, акумулювання історичної пам'яті: «Можна твердити, що нема такої української політичної течії, яка більшою чи меншою мірою не виросла з геніальної «Історії України-Руси». Тим то праця ця конечна для кожного політично мислячого українця, якщо він хоче мислити самостійно, за першоджерелами, а не за жуйкою, яку йому постачають журналісти і - ох же, як часто, - мало культурні журналісти» [16: 3]. Отже, видання праць М. Грушевського - це ще один внесок у формуванні української національної культурної «клітини» з етнічним ядром. До того ж це заплановане видання мало ще одну функцію: зберегти віру у власні сили серед української діаспори, бо, на думку автора статті, останнім часом з'явилося багато сумнівів щодо потрібності її діяльності, зневіри, замикання на власних інтересах.

Думки Ю. Шевельова про ментальну репрезентацію української культури отримали своє продовження у статті «Що таке Номис? Чому Номис?». Особливу увагу він приділяє українській фольклористиці, зокрема збірці питомих українських прислів'їв та приказок Номиса (Матвія Симоніва). Мабуть, тому, що видання $є$ не лише 
Яиенко А.

хорошим посібником для мовознавців, письменників та журналістів, а й орієнтиром ідентичності для української молоді поза межами України, бо вдало репрезентує багатошаровість українського етнічного менталітету: «колективні емоції», «етнонаціональний характер та темперамент», «поведінкові зразки», «стиль мислення і соціального сприйняття», «мову» [17]. «Номис - найкраща, найповніша наша збірка прислів'їв і приказок, їх тут подано не сотні, а тисячі. У певному сенсі це світ української людини на той час, середину дев’ятнадцятого століття, коли ці приказки записано з живої мови...» [18: 2], - пише публіцист. Мовознавець акцентує, що багато українців як на батьківщині, так і в еміграції, не знають, хто такий Номис, але його книжка - це «національний скарб», особливо в умовах двомовності як радянських українців, так і діаспорних, тож вітає ініціативу Академії наук її перевидати, а також наукову конференцію в Нью-Йорку, де доповідачі акцентували на історії видання та мовно-ментальних особливостях. Знову ж таки йдеться про формування українського ментального ядра для українців незалежно від ареалу проживання.

Низка статей Ю. Шевельова присвячена науковій та культурній діяльності української еміграції. У газеті «Свобода» з'являється декілька публікацій, ідейно-тематично пов’язаних між собою: «3 перспективи десятиріччя», «Проблеми розвитку української науки», «Перед склянкою води», «Український Музей у Ню Йорку яким хотіли б його бачити: Надія Світлична, Петро Холодний, Михайло Черешньовський, Юрій Шевельов, Управа Музею». Перші дві статті (одна 3 них - це промова 3 нагоди відкриття нового будинку УВАН у США) - своєрідний звіт про діяльність Української вільної академії наук у США, президентом якої був Ю. Шевельов, а також програма діяльності цієї наукової установи на майбутнє, а, отже, це акцентована роль української діаспори в українській культурній сфері. Публіцист наголошує, що УВАН за десять років існування змогла виконати свою основну роль: «об'єднати розпорошених українських науковців», «знайти визнання в американському науковому світі», а також спричинила до зростання «численної групи молодих американських науковців українського роду» [19: 3]. Висловлює надію, що діяльність академії наук зможе стимулювати інтерес до української тематики в науковців Америки та Свропи, а наукові результати будуть корисними для науковців України, коли вона стане незалежною. За два роки Ю. Шевельов вже бачить потребу причинитися до розвитку української науки, хай вона ще досі під чужоземним пануванням. Під час своєї промови «Проблеми розвитку української науки» він наголошує на трьох основних завданнях УВАН. Перше - підтримувати українську науку, бо паростки, зокрема в царині українознавства, там вже нав'язуються (президент УВАН ілюструє це прикладами з мовознавчих конференцій у Харкові та Чернівцях), хоча молодим українським науковцям бракує досвіду, знання, розуміння тяглості історичних традицій, адже попередня українська інтелігенція або винищена, або в еміграції. Цей досвід мають передавати українські наукові установи 3-за кордону, але робити це, наголошує Ю. Шевельов, дуже тактовно, ознайомлюючи з новою методологією, відкриваючи забуте або незнане, поступово формуючи національну свідомість, щоб намагання одразу все «замалювати в жовто-блакитний» не спричинило зворотної реакції. «Наш обов'язок - говорити тут те, чого там сказати не можна; спростовувати неправду, яка часом шириться звідти; не давати, в міру наших сил, згаснути тому вогневі, який там так запопадливо згашують; створити доробок, який перейде в майбутнє і який $\mathrm{i}$ сьогодні відограватиме свою ролю там» [20: 2], - пише він. Друге завдання, на думку 
президента УВАН, це об’єктивність та чесність, яку повинні демонструвати українці в наукових координатах заокеанського світу. Прояви патріотизму варто ховати у своє серце, коли препаруєш наукові факти особливо в часи, коли, як пише мовознавець, шириться «хвиля антиукраїнізму»: «Безжальність люблячого хірурга - це те чого від нас вимагає Захід, і це те, чого вимагають посередньо і інтереси України» [20: 2].

Третє завдання - завадити асиміляції української еміграції та її національній амбівалентності. Адже люди, відірвані від Батьківщини, дуже часто перебувають поза питомим національним часопростором, так і поза культурним ареалом теперішнього перебування. «Малоприємний обов’язок - будити еміграцію з цього зціпеніння, силоміць відкривати і очі і змушувати бачити правду. Але це є обов'язок» [20: 2], - акцентує Ю. Шевельов. Отже, місія науковців-емігрантів не лише закумулювати здобутки української науки, які втрачені через трагічні історичні обставини в Україні, а й транслювати національну свідомість і в діаспорні осередки, і в поки що радянську Україну.

Прогностична публіцистика. Майже всю публіцистику Ю. Шевельова можна назвати прогностичною, адже і в ранній культурологічній публіцистиці, і в пізніших подорожніх нарисах $є$ віра в незалежну, перспективну Україну. Найрепрезентативнішою статтею із циклу прогностичної публіцистики варто назвати публікацію «Світло вночі», яка з'явилася напередодні одного з найбільших християнських свят - Великодня. Це інтенції Ю. Шевельова щодо віри, зради, покори, людяності та любові і водночас проекція Христового життя та воскресіння на історичну долю України. Україна, як і син Божий, на думку публіциста, вже пережила свою «Осанну» в 1917-1918 роках, ламання кісток у часи Голодомору, зраду, поділ за жеребом між іншими народами і тривалу путь на Голгофу, але залишилося багато вірних, тож хвиля воскресіння українського народу попереду. «Перед нашими очима встають до нового життя найстарші народи світу народи Сходу. Ми маємо: в ряді цих воскресень і наше місце, тільки черга наша приходить пізніше, бо складніші й трагічніші обставини цієї країни, що стоїть на межі Европи й Азії. Але цифри і факти з залізною неминучістю показують нам, шо черга нашою повстання з мертвих близиться. Сама дійність кричить: бути Україні!» [21: 2], - пише Ю. Шевельов. І лише від українців, їхнього схорону української України в серцях, віри, на його думку, залежить «правда нашого воскресіння».

Отже, за тематично-змістовими ознаками серії статей Ю. Шевельова на шпальтах найдавнішої американської газети «Свобода» можна поділити на мовознавчі, подорожні, культурологічні і прогностичні. За ідейним наповненням - це національно зорієнтована публіцистика, у якій основні акценти на збереженні історичної пам'яті, науковому та культурному розвитку, формуванні національної свідомості, європейському розвитку України як самостійної держави. Газетні виступи Ю. Шевельова можна означити також як «публіцистику дії», адже в її основі національні імперативи як для мешканців України, так і для українців діаспори.

\section{REFERENCES}

1. Михайлин І. П'ятий Харків у журналістиці Юрія Шевельова: феноменологічна та імперативна репрезентації. URL: http://www.kafedrajourn.org.ua/media/227 (дата звернення: 07.03.2019). 
Яиенко А.

2. До річниці розгрому «українізації». Свобода. 1982. 20 жовт. (Ч. 199). С. 3.

3. До річниці розгрому «українізації». Свобода. 1983. 25 лют. (Ч. 36). С. 3-4.

4. Шерех Юрій. Принципи і етапи большевицької політики щодо слов'янських мов у СРСР (крім російської). Свобода. 1947. 19 листоп. (Ч. 270). С. 3.

5. Шерех Юрій. Принципи і етапи большевицької політики щодо слов'янських мов у СРСР (крім російської). Свобода. 1947. 22 листоп. (Ч. 273). С. 3.

6. Шерех Юрій. Принципи і етапи большевицької політики щодо слов'янських мов у СРСР (крім російської). Свобода. 1947. 29 листоп. (Ч. 278). С. 3.

7. Шевельов Ю. Четвертий Харків // http://maidan.org.ua/2011/09/yurij-shevelovchetvertyj-harkiv/(дата звернення: 05.03.2019).

8. Шевельов Ю. Харків: подорожні враження і заклик. Свобода. 1990. 31 жовт. (Ч. 209). C. $2,4$.

9. Шевельов Ю. Харків: подорожні враження і заклик. Свобода. 1990. 30 жовт. (Ч. 208). С. 2.

10. Друзі Харкова. Свобода. 1992. 4 груд. (Ч. 230). С.3.

11. Шевельов Ю. Добрі новини з Харкова. Свобода. 1992. 4 груд. (Ч. 230). С. 3-4.

12. Шевельов Ю. Харків фестивальний і Харків на щодень. Свобода. 1993. 9 черв. (Ч. 108). С. 2.

13. Шевельов Ю. Харків фестивальний і Харків на щодень. Свобода. 1993. 10 черв. (Ч. 109). С. 2.

14. Шевельов Ю. Харків фестивальний і Харків на щодень. Свобода. 1993. 11 черв. (Ч. 110). С. 2.

15. Шевельов Ю. Добрі і не такі вже добрі новини з Харкова. Свобода.1994. 19 жовт. (Ч. 198). С. 2.

16. Шерех Юрій. Культурна подія. Свобода. 1954. 23 жовт. (Ч. 204). С. 2-3.

17. Юрій M., Алексієвець Л. Етнічний менталітет та його особливості. URL:http:// shron1.chtyvo.org.ua/Yurii_Mykhailo/Etnichnyi_mentalitet_ta_ioho_osoblyvosti.pdfI (дата звернення: 01.03.2019).

18. Шевельов Ю. Що таке Номис? Чому Номис? Свобода. 1984. 24 листоп. (Ч. 223). C. 2,4 .

19. Шевельов Ю. 3 перспективи десятиріччя. Свобода. 1960. 13 травн. (Ч. 91). С. 3.

20. Шевельов Ю. Проблеми розвитку української науки. Свобода. 1962. 8 лют. (Ч. 26). C. 2-3.

21. Шерех Юрій. Світло вночі. Свобода. 1988. 2 квіт. (Ч. 63). С. $2,4$.

22. Ю. Ш. Перед склянкою води. Свобода. 1976. 23 жовт. (Ч. 204). С. 2-3.

23. Шерех Юрій. Принципи і етапи большевицької політики щодо слов'янських мов у СРСР (крім російської). Свобода. 1947. 20 листоп. (Ч. 271). С. 3.

24. Шерех Юрій. Принципи і етапи большевицької політики щодо слов'янських мов у СРСР (крім російської). Свобода. 1947. 21 листоп. (Ч. 272). С. 3.

25. Шерех Юрій. Принципи і етапи большевицької політики щодо слов'янських мов у СРСР (крім російської). Свобода. 1947. 25 листоп. (Ч. 275). С. 3.

26. Шерех Юрій. Принципи і етапи большевицької політики щодо слов'янських мов у СРСР (крім російської). Свобода. 1947. 28 листоп. (Ч. 277). С. 3-4.

27. Шевельов Юрій Володимирович (Шерех): Матеріали до бібліографії / Упоряд.: А. Даниленко, Л. Чабан. Нью-Йорк: УВАН, 1998. 200 с. 
28. Український Музей у Ню Йорку яким хотіли б його бачити: Надія Світлична, Петро Холодний, Михайло Черешньовський, Юрій Шевельов, Управа Музею. Свобода. 1982. 19 січ. (Ч. 11). С. 3.

29. Шерех Юрій. Минуле, що лишається живим: (Про діяльність київських мовознавців 20-х років). Свобода. 1952. 29 листоп. (Ч. 278). С. 3.

30. Кіндрась К. «Я ніколи нікого не зрадив». Шевельов - з Шевельовим - про Шевельова... (і довкруги). Свобода. 2002. 1 лют. (Ч. 5). С. 3-4.

31. О-КА. Про харків’янина, який полюбив Львів. Свобода. 2002. 19 квіт. (Ч. 16). С. 6. 32. Його науковий геній належить безсмертю. Свобода. 2002. 19 квіт. (Ч. 16). С. 1, 5.

\title{
JOURNALISM BY YURII SHEVELOV IN THE NEWSPAPER «SVOBODA» (USA)
}

\author{
Andrij Yatsenko \\ Ivan Franko National University of Lviv, \\ Generala Chuprynky Str., 49, 79044, Lviv, Ukraine \\ e-mail: andrij-jacenko@i.ua \\ https://orcid.org/0000-0002-7137-8305
}

In this article author highlights the main ideological and conceptual foundations of the political journalism of famous linguist Yurii Shevelov on the pages of «Svoboda» newspaper. The linguistic, traveler, cultural and prognostic aspects of Yurii Shevelov's speeches in the oldest Ukrainian-language American newspaper has been analyzed by the author.

The basis of the linguistic component of journalism of Yurii Shevelov in the «Svoboda» newspaper is the analytical article «Principles and stages of the Bolshevik policy towards Slavic languages in the USSR (except Russian)», in which the author clearly and consistently identifies for the first time the five main periods of development of the Ukrainian language in the Bolshevik era.

Another block of articles by Yurii Shevelov in the newspaper «Svoboda» can be defined as travel essays, that is, travel essay, because these are notes from travels to the «city of childhood» Kharkov. For four years, from 1990 to 1994, the linguist wrote about the impressions of the former capital of Ukraine through the prism of binary «friend-foe» dichotomies, trying to correctly highlight the accents and show the historical continuity of «Ukrainians» of Kharkov as the «north-eastern outpost of Ukraine».

The cultural problems of journalism of Yurii Shevelov are also many-sided: from the formation of the Ukrainian Free Academy of Sciences in the USA to the development of publishing in emigration and the latest productions of the young Ukrainian theater. The leitmotif of his articles, which appeared from 1954 to 1988, was the preservation of Ukrainian historical memory and at the same time the development of Ukrainian science and culture in a global context, and not in historically frozen traditions.

Interesting thing in predictive journalism by Yurii Shevelov from which follows the vision of Ukraine is an independent state on the geopolitical map of the world.

Key words: Yurii Shevelov, «Svoboda» newspaper, journalism, movable aspect, traveler aspect, prognostic aspect, culture, national idea. 